\title{
Base genética da resistência de um acesso de tomate silvestre ao mosaico-amarelo do pimentão
}

\author{
Ana Cristina Pinto Juhász ${ }^{(1)}$, Derly José Henriques da Silva(2), Francisco Murilo Zerbini Júnior ${ }^{(2)}$, \\ Pedro Crescêncio Souza Carneiro ${ }^{(2)}$, Bruno Oliveira Soares ${ }^{(2)}$ e Cosme Damião Cruz(2)
}

\begin{abstract}
(1)Empresa de Pesquisa Agropecuária de Minas Gerais, Epamig-CTNM, Rodovia MGT 122, Km 155, CEP 39525-000 Nova Porteirinha, MG. E-mail: anacpj@yahoo.com.br (2)Universidade Federal de Viçosa, Avenida P.H. Rolfs, s/no, CEP 36571-000 Viçosa, MG. E-mail: derly@ufv.br, zerbini@ufv.br, carneiro@ufv.br, brunoosoares@yahoo.com.br, cdcruz@ufv.br
\end{abstract}

\begin{abstract}
Resumo - O objetivo deste trabalho foi avaliar a base genética da resistência de Lycopersicon hirsutum ao potyvírus Pepper yellow mosaic virus (PepYMV). Foram avaliadas 540 plantas, inclusive os parentais 'Santa Clara' (suscetível) e 'BGH 6902' (resistente), e as gerações $\mathrm{F}_{1}, \mathrm{~F}_{2}, \mathrm{RC}_{1: 1}$ e $\mathrm{RC}_{1: 2}$, derivadas do cruzamento desses parentais. As plantas receberam inoculações mecanicamente, e a concentração viral de PepYMV em cada planta foi determinada por ELISA indireto. Foram realizadas as análises quantitativa e qualitativa. A primeira, baseada na concentração viral de cada planta, indicou herança oligogênica com herdabilidade de 99\%. Os mesmos dados, quando analisados de forma qualitativa, indicaram herança governada por dois genes, com interação epistática dominante e recessiva. Entretanto, quando foi analisada a geração $F_{2: 3}$, oriunda da autofecundação de plantas $\mathrm{F}_{2}$ resistentes, a hipótese de dois genes foi descartada e a de um gene, com dominância completa entre os alelos, foi a que melhor se ajustou aos dados. A análise qualitativa, pela sintomatologia observada, demonstrou que a herança da resistência ao PepYMV é determinada por um gene recessivo, com ausência de dominância entre os seus alelos.
\end{abstract}

Termos para indexação: Lycopersicon hirsutum, Pepper yellow mosaic virus, herança da resistência, resistência recessiva.

\section{Resistance genetic basis of a wild tomato access to pepper yellow mosaic virus}

\begin{abstract}
The aim of this work was to evaluate the genetic basis of resistance of Lycopersicon hirsutum to the potyvirus Pepper yellow mosaic virus (PepYMV). Five hundred and forty plants, including the parentals 'Santa Clara' (susceptible) and 'BGH 6902' (resistant) were evaluated, as well as the generations $\mathrm{F}_{1}, \mathrm{~F}_{2}, \mathrm{RC}_{1: 1}$ and $\mathrm{RC}_{1: 2}$, from the crossing of the above parentals. PepYMV was mechanically inoculated, and the virus concentration in each plant was determined by indirect ELISA. The quantitative and qualitative analyses were carried out. The first one, based on the virus concentration of each plant, suggest oligogenic inheritance with heritability of $99 \%$. The same data, when analyzed under the qualitative form, indicated an inheritance governed by two genes, with dominant and recessive epistatic interaction. However, when $\mathrm{F}_{2: 3}$ generation, arising from self-fertilization of resistant $\mathrm{F}_{2}$ plants, was analyzed, the hypothesis of two genes was rejected, while the best fitted to data was that of one gene with complete dominance among the alleles. The qualitative analysis, considering sintomatology observed, showed that the inheritance of resistance to PepYMV is determined by a recessive gene, with the absence of dominance among their alleles.
\end{abstract}

Index terms: Lycopersicon hirsutum, Pepper yellow mosaic virus, inheritance of resistance, recessive resistance.

\section{Introdução}

O tomateiro é uma cultura de grande importância econômica, e o Brasil é o oitavo produtor mundial de tomate e o maior da América latina (Silva \& Giordano, 2000). No entanto, é uma cultura sujeita à incidência de várias doenças, entre as quais as viroses, que podem se tornar fatores limitantes à produção, quando a cultivar não apresentar nível adequado de resistência genética (Kurozawa \& Pavan, 1997).

No Brasil, as principais viroses do tomateiro são: o vira-cabeça, causado por espécies do gênero Tospovirus (Pozzer et al., 1996), e o mosaico, causado por espécies do gênero Begomovirus da família Geminiviridae (Ribeiro et al., 2003). A espécie Pepper yellow mosaic virus (PepYMV, Potyviridae, Potyvirus), descrita a 
partir de plantas de pimentão (Inoue-Nagata et al., 2002), também infecta o tomateiro. A incidência do PepYMV em plantios de tomateiro vem aumentando no Brasil, com relatos recentes de perdas de até $100 \%$ no Espírito Santo (Ávila et al., 2004; Maciel-Zambolim et al., 2004).

A infecção do tomateiro pelo PepYMV resulta em doença severa, com sintomas de mosaico intenso, deformação foliar, definhamento das plantas e redução da produção de frutos (Maciel-Zambolim et al., 2004). Como controle, a resistência genética é o único meio seguro de se impedir que a doença se instale na lavoura e cause prejuízos aos produtores.

Em tomate, fontes de resistência a viroses têm sido relatadas mais comumente nas espécies silvestres de Lycopersicon, principalmente em L. peruvianum, L. pimpinellifolium, L. chilense e L. hirsutum (Giordano \& Silva, 1999). Para o PepYMV, Juhász et al. (2006) identificaram uma fonte de resistência, em um acesso de L. hirsutum pertencente ao Banco de Germoplasma de Hortaliças da Universidade Federal de Viçosa (BGH-UFV).

Após a identificação da fonte, é necessário determinar o controle genético da resistência, para se estabelecer em estratégias e se estimar a eficiência de uso dessa fonte, em programas de melhoramento.

O presente trabalho teve como objetivo avaliar a base genética da resistência de Lycopersicon hirsutum ao potyvírus Pepper yellow mosaic virus (PepYMV).

\section{Material e Métodos}

A primeira etapa do trabalho foi a de hibridação, para obtenção das sementes do híbrido $\mathrm{F}_{1}$, das gerações segregantes $\mathrm{F}_{2}$ e dos retrocruzamentos $\left(\mathrm{RC}_{1: 1}\right.$ e $\left.\mathrm{RC}_{1: 2}\right)$. As sementes híbridas $\mathrm{F}_{1}$ foram obtidas pelo cruzamento da cultivar Santa Clara, suscetível ao PepYMV, e do acesso resistente de L. hirsutum (BGH 6902). Para a realização dos cruzamentos, os genitores foram cultivados em estufa, na Horta de Pesquisa da Universidade Federal de Viçosa, Viçosa, MG, de janeiro a junho de 2004. Foram utilizadas 50 plantas da cultivar suscetível $\left(\mathrm{P}_{1}\right)$, como genitores femininos, e 10 plantas do acesso resistente $\left(\mathrm{P}_{2}\right)$ como doadores de pólen.

A partir do início do florescimento, o pólen das flores do genitor masculino foi coletado e armazenado em cápsulas de gelatina, em baixa temperatura e umidade. Os cruzamentos foram realizados, tendo se feito a emasculação e, em seguida, a polinização nos botões florais do genitor feminino, no período da manhã, entre
6 e $8 \mathrm{~h}$. As flores polinizadas artificialmente foram marcadas com lãs coloridas, a fim de se fazer a identificação nos frutos. Quando maduros, os frutos dos cruzamentos foram colhidos, as sementes retiradas manualmente, fermentadas por 48 horas, lavadas, secadas à temperatura ambiente e armazenadas em câmara fria, em baixa temperatura e umidade.

Para a obtenção dos retrocruzamentos, $\mathrm{RC}_{1: 1}\left(\mathrm{P}_{1} \mathrm{x}\right.$ $\left.F_{1}\right)$ e $R_{1: 2}\left(F_{1} \times P_{2}\right), 50$ plantas de $P_{1}, 10$ de $P_{2}$ e 30 de $F_{1}$ foram cultivadas em estufa, na Horta de Pesquisa da UFV, de julho a dezembro de 2004. A geração $F_{2}$ foi obtida pela autofecundação das plantas $F_{1}$. Os cruzamentos foram realizados conforme os mesmos procedimentos descritos para a obtenção da geração híbrida $F_{1}$. Nos cruzamentos, utilizaram-se os genitores femininos com maior carga genética de L. esculentum, com o objetivo de se obter maior taxa de pegamento e maior facilidade na determinação da época de colheita dos frutos, para a extração de sementes.

Após a obtenção das sementes das seis gerações os genitores $\left(\mathrm{P}_{1} \mathrm{e} \mathrm{P}_{2}\right)$, o híbrido $\mathrm{F}_{1}$, a geração segregante $\mathrm{F}_{2}$ e os retrocruzamentos $\left(\mathrm{RC}_{1: 1}\right.$ e $\left.\mathrm{RC}_{1: 2}\right)$-, as plantas foram cultivadas em casa de vegetação do Departamento de Fitopatologia da UFV, de maio a julho de 2005. Foram cultivadas 30 plantas, de cada um dos genitores e do híbrido $F_{1}, 250$ plantas da geração $F_{2}$, e 100 plantas de cada geração de retrocruzamento $\left(\mathrm{RC}_{1: 1}\right.$ e $\mathrm{RC}_{1: 2}$ ), no total de 540 plantas.

Realizado o estudo da herança da resistência, com base nas gerações acima, foi feita uma avaliação de 20 plantas da geração $F_{2: 3}$, obtidas da autofecundação de 10 plantas resistentes da geração $F_{2}$, para a confirmação do número estimado de genes responsáveis pela resistência ao PepYMV.

A inoculação do vírus nas plantas foi feita mecanicamente, tendo-se utilizado como fonte de inóculo, plantas de Nicotiana debneyi Domin infectadas com o isolado 3 do PepYMV. O isolado viral foi obtido de plantas de pimentão, coletadas em campo no Município de Igarapé, Estado de Minas Gerais (Truta et al., 2004). O preparo do inóculo foi realizado pela maceração de cada grama de folha de Nicotiana infectada, em $5 \mathrm{~mL}$ de tampão fosfato de potássio $0,05 \mathrm{M}, \mathrm{pH} 7,2$, com sulfito de sódio a $0,01 \%$, e com uso de Carborundum (600 mesh) como abrasivo. Para uniformizar a inoculação, com o auxílio de uma gaze, cada uma das duas folhas mais jovens de cada planta, com folhas totalmente estendidas, foi friccionada por três a quatro vezes com o inóculo. Para minimizar a incidência de escapes, as plantas receberam inoculações por cinco 
vezes, com intervalo de 48 horas entre cada inoculação. A primeira inoculação foi feita quando as plantas estavam no estádio de duas a quatro folhas definitivas.

As plantas foram mantidas em casa de vegetação e avaliadas visualmente até o surgimento de sintomas. A concentração viral de cada planta foi determinada por ELISA indireto (Clark et al., 1986), 15 dias após a primeira inoculação.

Para o ELISA, foram coletadas duas a três folhas do ápice das plantas, maceradas na proporção de $1 \mathrm{~g}$ de tecido foliar fresco para $5 \mathrm{~mL}$ de tampão (p/v). Foram utilizadas amostras de plantas sadias, sem inoculação, como controle negativo, e amostras de plantas de $N$. debneyi infectadas com o isolado 3 do PepYMV, como controle positivo. Após a reação enzimática, a intensidade de coloração foi medida em leitora Titertek Multiskan Plus MK II, a 405 nm.

Para a análise dos resultados, foram utilizadas abordagens quantitativa e qualitativa. No primeiro caso, a análise foi baseada nas médias e variâncias das gerações parentais, $\mathrm{F}_{1}, \mathrm{~F}_{2}, \mathrm{RC}_{1: 1}$ e $\mathrm{RC}_{1: 2}$, cujos valores foram obtidos pelo teste de ELISA, referentes à concentração viral presente em cada planta de cada geração. A análise das médias das gerações foi realizada segundo o modelo aditivo-dominante, em que as variações nas médias foram atribuídas apenas aos efeitos da média dos homozigotos ( $m$ ), do efeito aditivo (a) e do desvio de dominância (d). Os parâmetros genéticos foram estimados por meio do método dos mínimos quadrados ponderados (Cruz, 2006).

A partir da análise das variâncias das gerações, foram obtidas as seguintes estimativas (Cruz, 2006):

Variância ambiental $\left(\hat{\sigma}_{\mathrm{we}}^{2}\right): \hat{\sigma}_{\mathrm{we}}^{2}=\hat{\sigma}_{\mathrm{P} 2}^{2}$

Variância fenotípica $\left(\hat{\sigma}_{\mathrm{f}}^{2}\right): \hat{\sigma}_{\mathrm{f}=}^{2} \hat{\sigma}_{\mathrm{F} 2}^{2}$

Variância genotípica $\left(\hat{\sigma}_{\mathrm{g}}^{2}\right): \hat{\sigma}_{\mathrm{g}}^{2}=\hat{\sigma}_{\mathrm{F} 2}^{2}-\hat{\sigma}_{\mathrm{we}}^{2}$

Variância aditiva $\left(\hat{\sigma}_{\mathrm{a}}^{2}\right): \hat{\sigma}_{\mathrm{a}}^{2}=2 \hat{\sigma}_{\mathrm{F} 2}^{2}-\left(\hat{\sigma}_{\mathrm{RC} 1: 1+}^{2} \hat{\sigma}_{\mathrm{RC} 1: 2}^{2}\right)$

Herdabilidade no sentido amplo $\left(\mathrm{h}_{\mathrm{a}}^{2}\right): \mathrm{h}_{\mathrm{a}}^{2}=\frac{\hat{\sigma}_{\mathrm{g}}^{2}}{\hat{\sigma}_{\mathrm{F} 2}^{2}}$

Número mínimo de genes envolvidos na determinação

do caráter $(\eta): \eta=\frac{R^{2}\left(1+0,5 k^{2}\right)}{8 \hat{\sigma}_{g}^{2}}$

em que $\hat{\sigma}_{\mathrm{P} 2}^{2}$ é a variância do $\mathrm{P}_{2} ; \hat{\sigma}_{\mathrm{F} 1}^{2}$ é a variância do $\mathrm{F}_{1}$; $\hat{\sigma}_{\mathrm{F} 2}^{2}$ é a variância do $\mathrm{F}_{2} ; \hat{\sigma}_{\mathrm{RC} 1: 1}^{2}$ é a variância do $\mathrm{RC}_{1: 1}$; $\hat{\sigma}_{\mathrm{RC1} 12}^{2}$ é a variância do $\mathrm{RC}_{1: 2} ; \mathrm{R}^{2}$ é a amplitude total na $\mathrm{F}_{2} ; \mathrm{k}=\mathrm{GMD}$.
Essas análises foram realizadas com o auxílio do programa computacional GENES (Cruz, 2006).

$\mathrm{Na}$ abordagem qualitativa, três análises foram realizadas. Na primeira, as plantas foram consideradas resistentes ou suscetíveis, a partir dos valores de concentração viral obtidos por ELISA, tendo sido a classificação das plantas (resistentes ou suscetíveis) feita de acordo com o seguinte ponto de corte, para os resultados do ELISA: plantas cujos valores de absorbância foram duas vezes maiores ou iguais ao do controle negativo foram consideradas suscetíveis; e plantas com valores inferiores a duas vezes o controle negativo foram consideradas resistentes. Na segunda análise, as plantas foram consideradas resistentes ou suscetíveis, de acordo com a ausência ou presença de sintomas, respectivamente. Na terceira análise, o estudo de herança foi baseado na avaliação dos sintomas, que resultou em três classes: sintomas fortes, fracos e ausência de sintomas. Nas três análises qualitativas, foi utilizado o teste de qui-quadrado $\left(\chi^{2}\right)$, a $5 \%$ de probabilidade, para adequar as proporções observadas, em cada geração avaliada, àquelas esperadas, com base na respectiva hipótese do número de genes envolvidos no controle do caráter resistência ao PepYMV. O quiquadrado calculado $\left(\chi_{c}^{2}\right)$ foi estimado por meio da estatística:

$$
\chi_{c}^{2}=\sum_{i-1}^{k} \frac{\left(O_{i}-E_{i}\right)^{2}}{E_{i}}
$$

em que: $\mathrm{O}_{\mathrm{i}}$ é o número observado de indivíduos na i-ésima classe fenotípica; $\mathrm{E}_{\mathrm{i}}$ é o número esperado de indivíduos na i-ésima classe fenotípica; $\mathrm{k}$ é o número de classes fenotípicas.

\section{Resultados e Discussão}

Após a inoculação com o PepYMV, todas as plantas do genitor suscetível $P_{1}$ apresentaram sintomas intensos de mosaico (Figura $1 \mathrm{~A}$ ), enquanto nas plantas do genitor resistente $\mathrm{P}_{2}$ não foi detectado nenhum sintoma de virose (Figura $1 \mathrm{~B}$ ). Cabe ressaltar que a resistência de $\mathrm{P}_{2}$ foi confirmada pelo teste de ELISA. Na geração $F_{1}$, todas as plantas desenvolveram sintomas fracos (Figura $1 \mathrm{C}$ ) $\mathrm{e}$, na geração $\mathrm{F}_{2}$, houve grande variação de sintomas (Figura $1 \mathrm{D}, \mathrm{E}$ e F).

$\mathrm{Na}$ análise quantitativa, a herança da resistência foi determinada por meio dos valores de absorbância, obtidos por ELISA, referentes à concentração viral presente 
em cada planta de cada geração (Tabela 1). O genitor resistente $\left(\mathrm{P}_{2}\right)$ obteve concentração viral média inferior ao controle negativo, cuja média foi 0,099 , e menor variância em relação às outras gerações, o que confirma a sua resistência. Foram observadas nas gerações $F_{1}$, $\mathrm{F}_{2}$ e $\mathrm{RC}_{1: 1}$ valores médios de concentração viral próximo ao do genitor suscetível $\left(\mathrm{P}_{1}\right)$.

A estimativa de parâmetros genéticos, a partir das variâncias das gerações, indica que a herança da resistência ao PepYMV seja determinada por mais de um gene $(\eta=1,59)$, porém com elevada herdabilidade $(99,22 \%)$. A variância fenotípica $\left(\sigma_{\mathrm{F} 2}^{2}\right)$ foi de 0,030514 , a genotípica $\left(\sigma_{\mathrm{g}}^{2}\right)$ de 0,030277 , e a ambiental $\left(\sigma_{\mathrm{we}}^{2}\right)$ de 0,000238 . Observou-se, ainda, segregação transgressiva na geração $F_{2}$, em que foi detectado para algumas plantas o valor máximo de 0,76 e o mínimo de 0,056 de concentração viral, fora dos limites superior e inferior dos genitores. Tal fato é evidência de que mais de um gene pode estar envolvido na determinação da resistência ao PepYMV, ou que o teste ELISA apresenta pequena influência ambiental na avaliação da resistência.
A partir da análise da média de gerações, verificouse que o modelo aditivo-dominante, apenas com os parâmetros $\mathrm{m}$, a e d, foi adequado para explicar os efeitos gênicos envolvidos na herança da resistência, o que indica que efeitos epistáticos não foram importantes no controle genético das características avaliadas, uma vez que o coeficiente de determinação para o ajuste a este modelo foi de $96,48 \%$. O efeito aditivo foi o mais importante na determinação do caráter, pois explica $83,89 \%$ da variação total, e o grau médio de dominância (baseado em médias) foi igual a um, o que indica dominância completa. O efeito dominante foi o menos significativo $\left(R^{2}=0,38\right)$. Os efeitos epistáticos (aditivoaditivo, aditivo-dominante e dominante-dominante) corresponderam a $3,52 \%$ do total da epistasia

Pela análise qualitativa da herança da resistência ao PepYMV, e pelas leituras de absorbância relativa à concentração viral de PepYMV por ELISA nas folhas das plantas, 52 plantas foram consideradas resistentes e 198 suscetíveis. Foram testadas duas hipóteses de segregação de plantas resistentes para suscetíveis: de 1:3,
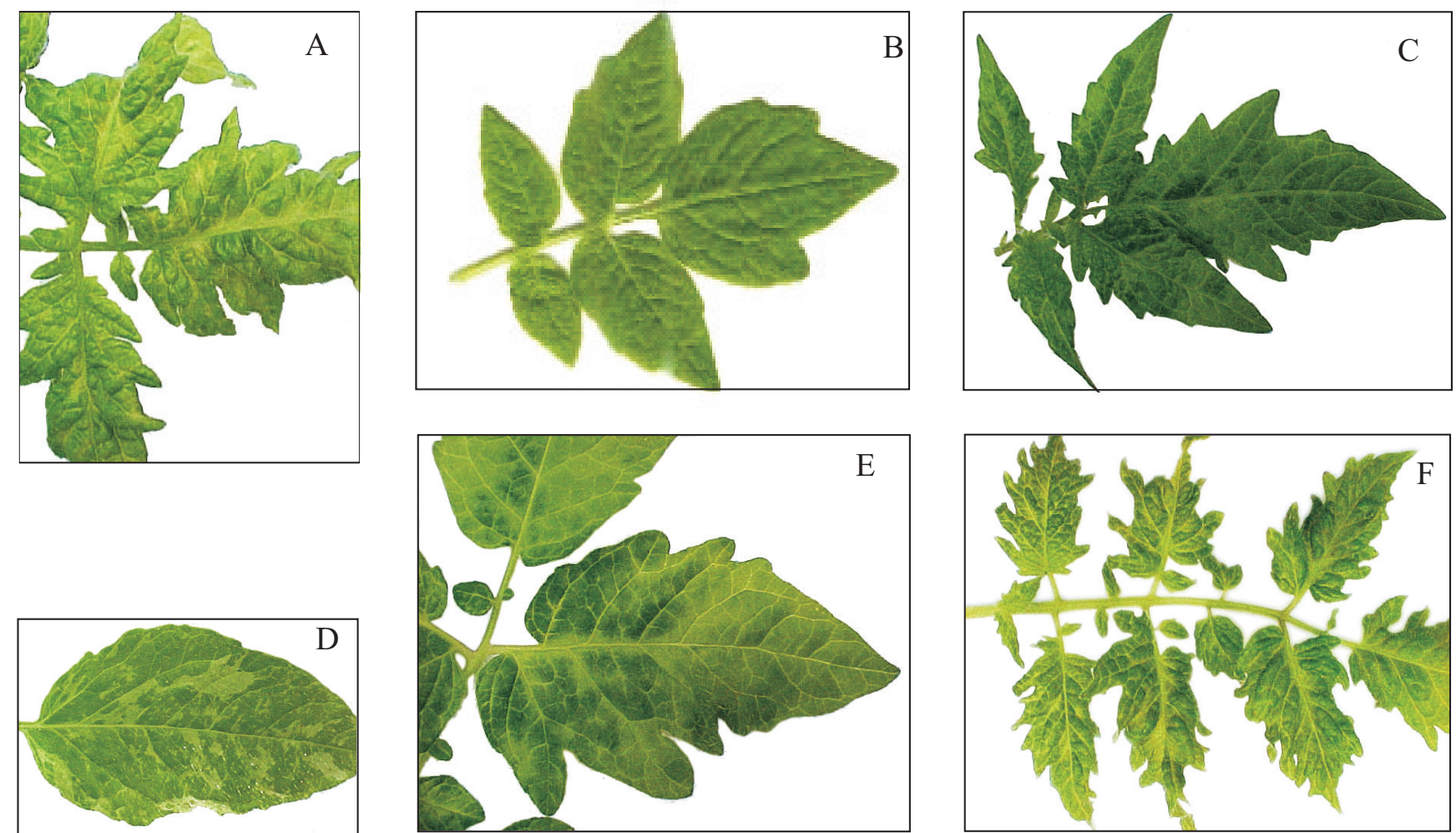

Figura 1. Variação de sintomas de mosaico, em folhas de tomate, 20 dias após a inoculação com o vírus PepYMV. A, folha de tomate do genitor suscetível $\mathrm{P}_{1}$ (Santa Clara); $\mathrm{B}$, folha de tomate do genitor resistente $\mathrm{P}_{2}$ (acesso BGH 6902); C, folha do híbrido $\mathrm{F}_{1}$, obtido do cruzamento Santa Clara x BGH 6902; D, E e F, folhas de tomate da geração $\mathrm{F}_{2}$, obtidas a partir da autofecundação de $\mathrm{F}_{1}$. 
em que um único gene recessivo é responsável pela resistência; e de 3:13, em que dois genes independentes determinam a resistência. Ambas não foram rejeitadas, a $5 \%$ de probabilidade, pelo teste do qui-quadrado. Cabe ressaltar que a hipótese de dois genes, com epistasia dominante e recessiva (3:13), apresentou maior nível de significância $(\alpha=40,6 \%)$ do que a hipótese de um gene de 1:3 $(\alpha=12,5 \%)$, o que indica que a hipótese de dois genes é a mais indicada para explicar a herança da resistência de L. hirsutum ao PepYMV. Neste caso, o genótipo de cada uma das gerações avaliadas seria representado da seguinte forma: $\mathrm{P}_{1}, \mathrm{AAbb}$ (suscetível); $\mathrm{P}_{2}$, aaBB (resistente); $\mathrm{F}_{1}, \mathrm{AaBb}$ (suscetível); $\mathrm{RC}_{1: 1}$, (1) A_B_ (suscetível):(1) A_bb (suscetível); $\mathrm{RC}_{1: 2}$, (1) A_B_ (suscetível):(1) aaB _ (resistente); $\mathrm{F}_{2}$, (9) A_B_ (suscetível):(3) A_bb (suscetível): (3) aaB_ (resistente):(1) aabb (suscetível), em que seriam resistentes apenas as plantas em homozigose para o alelo a na presença do alelo B.

Shuster \& Cruz (2004) citam que para distinguir estas duas razões de segregação (1:3 e 3:13), a 5\% de probabilidade, seria necessária a análise de no mínimo 660 plantas na geração $\mathrm{F}_{2}$.

Como alternativa à análise de um elevado número de plantas da geração $F_{2}$, para a distinção entre as duas hipóteses de segregação (3:13 e 1:3), foram avaliadas plantas da geração $F_{2: 3}$. Não se observaram sintomas em nenhuma das plantas da geração $\mathrm{F}_{2: 3}$ infectadas e, o valor de concentração viral de todas essas plantas foi inferior ao controle negativo.

Com base na hipótese de dois genes, espera-se, em $\mathrm{F}_{2}$, que a probabilidade de ocorrência do genótipo resistente ser aaBB seja de $1 / 16$, enquanto a de ser aaBb seja de $2 / 16$; $\log$ o, a probabilidade de as plantas resistentes avaliadas serem do genótipo aaBB é de 1/3,

Tabela 1. Número de plantas avaliadas, médias e variâncias das gerações $\mathrm{P}_{1}, \mathrm{P}_{2}, \mathrm{~F}_{1}, \mathrm{~F}_{2}, \mathrm{RC}_{1: 1}$ e $\mathrm{RC}_{1: 2}$ obtidas a partir do cruzamento do tomateiro 'Santa Clara' x 'BGH 6902', determinadas pela leitura de absorbância relativa à concentração viral de PepYMV, nas folhas das plantas das diferentes gerações, mediante o teste de ELISA.

\begin{tabular}{lccc}
\hline Geração & Número de plantas & Média & Variância \\
\hline $\mathrm{P}_{1}$ & 30 & 0,308313 & 0,004238 \\
$\mathrm{P}_{2}$ & 30 & 0,092257 & 0,000238 \\
$\mathrm{~F}_{1}$ & 30 & 0,320433 & 0,006490 \\
$\mathrm{~F}_{2}$ & 250 & 0,312724 & 0,030514 \\
$\mathrm{RC}_{1: 1}$ & 100 & 0,315049 & 0,006055 \\
$\mathrm{RC}_{1: 2}$ & 100 & 0,230292 & 0,015556 \\
\hline
\end{tabular}

enquanto a de serem aaBb é de $2 / 3$. Assim, se a herança da resistência ao PepYMV for realmente relativa a dois genes com epistasia dominante e recessiva, espera-se que na descendência das plantas resistentes, pelo menos uma planta suscetível ocorra, com probabilidade igual a [1-(3/4)20 x 2/3]10. Como na avaliação das 20 plantas, de cada uma das 10 resistentes em $\mathrm{F}_{2}$, todas foram resistentes, o erro em se afirmar que dois genes estariam envolvidos na determinação da resistência é dado por [1-(3/4)20 x 2/3]10. Assim, a probabilidade em se afirmar que um único gene recessivo determina a resistência de L. hirsutum ao PepYMV é dada pela expressão $\mathrm{P}=1-[1-(3 / 4) 20 \times 2 / 3] 10$ (Cruz et al., 2001), que, neste caso, correspondeu a $98,32 \%$ de probabilidade, o que indica ser a hipótese de um único gene recessivo, com dominância completa, a hipótese mais provável para explicar a herança da resistência ao PepYMV.

$\mathrm{Na}$ segunda análise qualitativa da herança da resistência ao PepYMV, via análise dos sintomas, e tendo-se considerado apenas as classes resistência (na ausência de sintomas) e suscetibilidade (presença de sintomas, fracos ou fortes), a proporção esperada de segregação de plantas resistentes para suscetíveis foi de $0: 1,0: 1,1: 1$ e 3:1, respectivamente, para as gerações $\mathrm{F}_{1}, \mathrm{RC}_{1: 1}, \mathrm{RC}_{1: 2}$ e $\mathrm{F}_{2}$ (Tabela 2). Em todos os casos, estas hipóteses não foram rejeitadas, com o menor valor de probabilidade associado igual a $27,33 \%$, o que indica que a resistência seja controlada por um gene recessivo, com interação entre os alelos de dominância completa.

Entretanto, ao se considerar a sintomatologia observada, foram distinguidas três classes na geração $\mathrm{F}_{2}$ : plantas com ausência de sintomas, plantas com sintomas fracos e plantas com sintomas fortes (Tabela 3 ).

Tabela 2. Teste do qui-quadrado $\left(\chi^{2}\right)$ para número de plantas resistentes (ausência de sintomas) e suscetíveis (com sintomas), nas gerações obtidas a partir do cruzamento 'Santa Clara' x 'BGH 6902'.

\begin{tabular}{lrrrrr}
\hline Geração & \multicolumn{3}{c}{$\mathrm{N}^{-}$de plantas } & Hipótese & $\chi^{2}$ \\
\cline { 2 - 3 } & Total & Resistente & Suscetível & & \\
\hline $\mathrm{P}_{1}$ & 30 & 0 & 30 & $0: 1$ & $0(100 \%)^{(1)}$ \\
$\mathrm{P}_{2}$ & 30 & 30 & 0 & $1: 0$ & $0(100 \%)$ \\
$\mathrm{F}_{1}$ & 30 & 0 & 30 & $0: 1$ & $0(100 \%)$ \\
$\mathrm{RC}_{1}$ & 100 & 0 & 100 & $0: 1$ & $0(100 \%)$ \\
$\mathrm{RC}_{2}$ & 100 & 49 & 51 & $1: 1$ & $0,04(84,14 \%)$ \\
$\mathrm{F}_{2}$ & 250 & 70 & 180 & $1: 3$ & $1,2(27,33 \%)$ \\
\hline
\end{tabular}

${ }^{(1)}$ Valores entre parênteses indicam a probabilidade associada ao valor do $\chi^{2}$ tabelado, com 1 GL $(3,841)$. 
Com base na análise destes dados, a resistência ao PepYMV é determinada por um gene recessivo, com ausência de dominância entre os alelos, visto que a hipótese esperada de 1:2:1 não foi rejeitada, com probabilidade associada de 40,6\%. Neste caso, o genótipo de cada uma das gerações avaliadas seria representado da seguinte forma: $\mathrm{P}_{1}$ : AA; $\mathrm{P}_{2}$ : aa; $\mathrm{F}_{1}$ : $\mathrm{Aa} ; \mathrm{RC}_{1: 1}$ : (1) Aa: (1) AA; $\mathrm{RC}_{1: 2}$ : (1) Aa: (1) aa; $\mathrm{F}_{2}$ : (1) AA : (2) Aa : (1) aa, em que seriam resistentes apenas as plantas em homozigose para o alelo a.

Resultados semelhantes foram relatados na literatura por Thomas \& McGrath (1988), que identificaram resistência monogênica recessiva de L. hirsutum ao PVY (Potato virus Y). Também há relatos de resistência controlada por dois genes recessivos (Legnani et al., 1995).

A resistência recessiva é citada na literatura, com maior freqüência para potyviroses (em torno de 40\%) do que para outras famílias de vírus (em torno de 20\%) (Provvidenti \& Hampton, 1992), nas quais a resistência parece ser predominantemente governada por genes dominantes (Fraiser, 1990), como por exemplo ao TSWV (Tomato spotted wilt virus) (Stevens et al., 1992; Boiteux \& Giordano, 1993) e ao CMV (Cucumber mosaic virus) (Stamova \& Chetelat, 2000) em tomateiro.

A clonagem e a caracterização de genes recessivos que conferem resistência a potyvírus foi realizada em pimentão (Ruffel et al., 2002), alface (Nicaise et al., 2003) e ervilha (Gao et al., 2004), para o Potato virus $Y$ (PVY), o Lettuce mosaic virus (LMV) e o Pea seedborne mosaic virus (PSbMV), respectivamente. Nos três casos, o fator de iniciação da tradução de eucariotos eIF4E foi identificado como o gene de resistência aos potyvírus. Em Arabidopsis, três genes
(eIF4E1, eIF4E2 e eIF4E3) já foram descritos como associados à resistência recessiva. Assim, o fator eIF4E pode ser considerado como pertencente a uma família de genes que conferem resistência a potyviroses (Robaglia \& Caranta, 2006).

Em pimentão e tomate, foi demonstrado que os genes pot-1 e $p v r 2$ conferem resistência recessiva completa ao Potato virus $Y$ (PVY) e ao Tobacco etch virus (TEV), respectivamente (Parrela et al., 2002; Ruffel et al., 2005; Yeam et al., 2007), em razão do mesmo fator de resistência recessiva a potyviroses (fator eIF4E).

Em razão de todas as plantas da $F_{1}$ terem desenvolvido sintomas fracos e de a hipótese de um gene, com ausência de dominância, estar associada à maior probabilidade ( $\alpha=40,62 \%)$ do que a hipótese com um gene e dominância completa $(\alpha=27,33 \%)$, pode-se concluir que a herança da resistência ao PepYMV é determinada por um único gene recessivo, com ausência de dominância entre os alelos. Também se conclui que a análise qualitativa, levando-se em consideração a sintomatologia das plantas, em relação ao PepYMV, foi mais adequada para se determinar a herança da resistência, uma vez que a análise quantitativa dos dados, por meio dos valores de absorbância relativa por ELISA, não foi suficiente para se distinguir a hipótese de um gene daquela de dois genes como responsáveis pela resistência. Entretanto, cabe ressaltar que quando esta análise foi complementada com a geração $\mathrm{F}_{2: 3}$, oriunda de plantas $\mathrm{F}_{2}$ resistentes, ela se tornou adequada para a determinação do número de genes envolvidos na herança da resistência ao PepYMV e deixou a desejar apenas quanto à determinação da interação entre os alelos.

Apesar de o acesso silvestre utilizado possuir várias características de planta e fruto muito diferenciadas dos

Tabela 3. Teste do qui-quadrado $\left(\chi^{2}\right)$, para número de plantas com ausência de sintomas, sintomas fracos e fortes, nas gerações obtidas a partir do cruzamento 'Santa Clara' x 'BGH 6902'.

\begin{tabular}{lccccrr}
\hline Geração & \multicolumn{3}{c}{$\mathrm{N}^{\mathbf{0}}$ de plantas } & Hipótese & $\chi^{2}$ \\
\cline { 2 - 5 } & Total & $\begin{array}{c}\text { Ausência de sintomas } \\
\text { (resistente) }\end{array}$ & $\begin{array}{c}\text { Sintomas fracos } \\
\text { (suscetível) }\end{array}$ & $\begin{array}{c}\text { Sintomas fortes } \\
\text { (suscetível) }\end{array}$ & & \\
\hline $\mathrm{P}_{1}$ & 30 & 0 & 0 & 30 & $0: 0: 1$ & $0(100 \%)^{(1)}$ \\
$\mathrm{P}_{2}$ & 30 & 30 & 0 & 0 & $1: 0: 0$ & $0(100 \%)$ \\
$\mathrm{F}_{1}$ & 30 & 0 & 30 & 0 & $0: 1: 0$ & $0(100 \%)$ \\
$\mathrm{RC}_{1: 1}$ & 100 & 0 & 53 & 47 & $0: 1: 1$ & $0,36(54,85 \%)$ \\
$\mathrm{RC}_{1: 2}$ & 100 & 51 & 49 & 0 & $1: 1: 0$ & $0,04(84,14 \%)$ \\
$\mathrm{F}_{2}$ & 250 & 70 & 125 & 55 & $1: 2: 1$ & $1,8(40,65)$ \\
\hline
\end{tabular}

(1) Valores entre parênteses indicam a probabilidade associada ao valor do $\chi^{2}$ tabelado, com 2 GL $(5,99)$. 
tipos cultivados comercialmente, o que pode acarretar em maior tempo para o lançamento de cultivares com características desejáveis, este acesso deve ser incorporado ao programa de melhoramento genético do tomateiro.

Pelo fato de ser apenas um gene que governa a resistência, o método dos retrocruzamentos, que inclui uma geração de autofecundação e inoculação para eliminação das plantas suscetíveis, seria o mais indicado para a transferência do gene de resistência.

\section{Conclusões}

1. A análise de gerações, complementada com a geração $\mathrm{F}_{2: 3}$, oriunda de plantas $\mathrm{F}_{2}$ resistentes, é adequada para a determinação do número de genes envolvidos na herança da resistência ao PepYMV, exceto para a interação entre os alelos.

2. A análise qualitativa, ao considerar a intensidade de sintomas das plantas, foi a mais adequada para se determinar o número de genes e a interação entre os alelos envolvidos na herança da resistência de tomateiro ao PepYMV.

3. A herança da resistência do acesso BGH 6902 de L. hirsutum ao isolado 3 do potyvírus PepYMV é determinada por um gene recessivo, com ausência de dominância entre os alelos.

\section{Referências}

ÁVILA, A.C.; IONUE-NAGATA, A.K.; COSTA, H.; BOITEUX, L.S.; NEVES, L.O.Q.; PRATES, R.S.; BERTINI, L.A. Ocorrência de viroses em tomate e pimentão na região serrana do Estado do Espírito Santo. Horticultura Brasileira, v.22, p.655-658, 2004.

BOITEUX, L.S.; GIORDANO, L.B. Genetic basis of resistance against two Tospovirus species in tomato (Lycopersicon esculentum). Euphytica, v.71, p.151-154, 1993.

CLARK, M.F.; LISTER, R.M.; BAR-JOSEPH, M. ELISA techniques. Methods in Enzymology, v.118, p.742-766, 1986.

CRUZ, C.D. Programa GENES: biometria. Viçosa: UFV, 2006. 382p.

CRUZ, C.D.; VIANA, J.M.S.; CARNEIRO, P.C.S. Genética: GBOL: software para ensino e aprendizagem de genética. Viçosa: UFV, 2001. v.2. 475p.

FRAISER, R.S.S. The genetics of resistance to plant viruses. Annual Review of Phytopathology, v.28, p.179-200, 1990.

GAO, Z.; JOHANSEN, E.; EYERS, S.; THOMAS, C.L.; NOEL ELLIS, T.H.; MAULE, A.J. The potyvirus recessive resistance gene, $s b m 1$, identifies a novel role for translation initiation factor eIF4E in cell-to-cell trafficking. Plant Journal, v.40, p.376-385, 2004.

GIORDANO, L.B.; SILVA, C. Hibridação em tomate. In: BORÉM, A. (Ed.). Hibridação artificial de plantas. Viçosa: UFV, 1999. p.463-480.
INOUE-NAGATA, A.K.; FONSECA, M.E.N.; RESENDE, R.O.; BOITEUX, L.S.; MONTE, D.C.; DUSI, A.N.; ÁVILA, A.C.; VAN DER VLUGT, R.A.A. Pepper yellow mosaic virus, a new potyvirus in sweetpepper, Capsicum annuum. Archives of Virology, v.147, p.849-855, 2002.

JUHÁSZ, A.C.P.; SILVA, D.J.H.; ZERBINI JÚNIOR, F.M.; SOARES, B.O.; AGUILERA, G.A.H. Screening of Lycopersicon sp. accessions for resistance to Pepper yellow mosaic virus. Scientia Agricola, v.63, p.510-512, 2006.

KUROZAWA, C.; PAVAN, M.A. Doenças do tomateiro. In: KIMATI, H.; AMORIM, L.; BERGAMIM FILHO, A.; CAMARGO, L.E.A.; REZENDE, J.A.M. (Ed.). Manual de fitopatologia: doenças das plantas cultivadas. São Paulo: Agronômica Ceres, 1997. v.2. p.690-719.

LEGNANI, R.; SELASSIE, G.; WOMDIM, R.N.; GOGNALONS, P.; MORETTI, A.; LATERROT, H.; MARCHOUX, G. Evaluation and inheritance of the Lycopersicon hirsutum resistance against Potato virus Y. Euphytica, v.86, p.219-226, 1995.

MACIEL-ZAMBOLIM, E.; COSTA, H.; CAPUCHO, A.S.; ÁVILA, A.C.; INOUE-NAGATA, A.K.; KITAJIMA, E.W. Surto epidemiológico do vírus do mosaico amarelo do pimentão em tomateiro na região serrana do Espírito Santo. Fitopatologia Brasileira, v.29, p.325-327, 2004.

NICAISE, V.; GERMAN-RETANA, S.; SANJUÁM, R.; DUBRANA, M.; MAZIER, M.; MAISONNEUVE, B.; CANDRESSE, T.; CARANTA, C.; LeGALL, O. The eukaryotic translation initiation factor 4E controls lettuce susceptibility to the potyvirus Lettuce mosaic virus. Plant Physiology, v.132, p.12721282, 2003.

PARRELLA, G.; RUFFEL, S.; MORETTI, A.; MOREL, C.; PALLOIX, A.; CARANTA, C. Recessive resistance genes against potyviruses are localized in colinear genomic regions of the tomato (Lycopersicon spp.) and pepper (Capsicum spp.) genomes. Theoretical and Applied Genetics, v.105, p.855-861, 2002.

POZZER, L.; RESENDE, R.O.; LIMA, M.I.; KITAJIMA, E.W.; GIORDANO, L.B.; ÁVILA, A.C. Tospovírus, uma visão atualizada. Revisão Anual de Patologia de Plantas, v.4, p.95-148, 1996.

PROVVIDENTI, R.; HAMPTON, R.O. Sources of resistance to viruses in the Potyviridae. Archives of Virology Supplementum, v.5, p.189-211, 1992.

RIBEIRO, S.G.; AMBROZEVÍCIUS, L.P.; ÁVILA, A.C.; BEZERRA, I.C.; CALEGARIO, R.F.; FERNANDES, J.J.; LIMA, M.F.; MELLO, R.N.; ROCHA, H.; ZERBINI, F.M. Distribution and genetic diversity of tomato-infecting begomoviruses in Brazil. Archives of Virology, v.148, p.281-295, 2003.

ROBAGLIA, C.; CARANTA, C. Translation initiation factors: a weal link in plant RNA virus infection. Trends in Plant Science, v.11, p.40-45, 2006.

RUFFEL, S.; DUSSAULT, M.; PALLOIX, A.; MOURY, B.; BENDAHMANE, A.; ROBAGLIA, C.; CARANTA, C. A natural recessive resistance gene against Potato virus $\mathrm{Y}$ in pepper corresponds to the eukaryotic initiation factor 4E (eIF4E). Plant Journal, v.32, p.1067-1075, 2002.

RUFFEL, S.; GALLOIS, J.L.; LESAGE, M.L.; CARANTA, C. The recessive potyvirus resistance gene pot 1 is the tomato orthologue 
of the pepper $p v r 2$-eIF4E gene. Molecular Genetics and Genomics, v.274, p.346-353, 2005.

SCHUSTER, I.; CRUZ, C.D. Estatística genômica aplicada a populações derivadas de cruzamentos controlados. Viçosa: UFV, 2004. 568p.

SILVA, J.B.C.; GIORDANO, L.B. Tomate para processamento industrial. Brasília: Embrapa Comunicação para Transferência de Tecnologia; Embrapa Hortaliças, 2000. 168p.

STAMOVA, B.S.; CHETELAT, R.T. Inheritance and genetic mapping of Cucumber mosaic virus resistance introgressed from Lycopersicon chilense into tomato. Theoretical and Applied Genetics, v.101, p.527-537, 2000.

STEVENS, M.R.; SCOTT, S.J.; GERGERICH, R.C. Inheritance of a gene for resistance to Tomato spotted wilt virus (TSWV) from Lycopersicon peruvianum Mill. Euphytica, v.59, p.9-17, 1992.

THOMAS, J.E.; McGRATH, D.J. Inheritance of resistance to Potato virus $\mathrm{Y}$ in tomato. Australian Journal of Agriculture Research, v.39, p.475-479, 1988.

TRUTA, A.A.C.; SOUZA, A.R.R.; NASCIMENTO, A.V.S.; PEREIRA, R.C.; PINTO, C.M.F.; BROMMONSCHENKEL, S.H.; CARVALHO, M.G.; ZERBINI, F.M. Identidade e propriedades de isolados de potyvírus provenientes de Capsicum spp. Fitopatologia Brasileira, v.29, p.160-168, 2004.

YEAM, I.; CAVATORTA, J.R.; RIPOLL, D.R.; KANG, B.; JAHN, M.M. Functional dissection of naturally occurring amino acid substitutions in eIF4E that confers recessive potyvirus resistance in plants. Plant Cell, v.19, p.2913-2928, 2007.

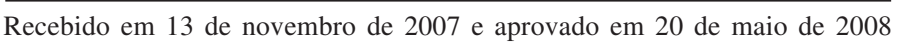

